\title{
The use of passive seismological imaging in speleogenetic studies: an example from Kanaan Cave, Lebanon
}

\author{
Carole Nehmé ${ }^{1,2 *}$, Christophe Voisin ${ }^{3,4}$, Armand Mariscal ${ }^{3,4}$, Pierre-Charles Gérard ${ }^{1,5}$, \\ Cécile Cornou ${ }^{3}$, Badr Jabbour-Gédéon ${ }^{1,2,5}$, Samer Amhaz ${ }^{5}$, Nancy Salloum ${ }^{3}$, \\ Nada Badaro-Saliba ${ }^{1}$, Jocelyne Adjizian-Gerard ${ }^{1,2}$, and Jean-Jacques Delannoy ${ }^{2}$ \\ ${ }^{1}$ Département de Géographie, Université Saint-Joseph, Beyrouth, Lebanon \\ 2 EDYTEM, Université de Savoie, 73376, Le Bourget du Lac, France \\ ${ }^{3}$ Institut des Sciences de la Terre, CNRS, IRD, Université Joseph Fourier, Maison des Géosciences, BP 53, 38041 Grenoble, France \\ ${ }^{4}$ CNRSL, Centre de Recherches Géophysiques, Bhannès, Lebanon \\ ${ }^{5}$ ALES, Association Libanaise d'Etudes Spéléologiques, Mansourieh El-Matn, Lebanon
}

\begin{abstract}
Among many parameters that control the evolution of caves stands the volume of unconsolidated clay sediments generally produced by the alteration of the calcareous rocks. Here we introduce the use of a passive seismological imaging technique to investigate the clay deposits and estimate its total volume in a cave. Applied for the first time for speleogenesis studies, the HVSR (Horizontal / Vertical Spectral Ratio) is a geophysical technique that can help better interpret cave geomorphology. We apply seismological spectral techniques ( $\mathrm{H} / \mathrm{V}$ ratio) on ambient noise vibrations to derive the clay volume, as well as its shape. This technique applied on the clay volume reveals some internal details, such as fallen blocks prior to the deposit accumulation and helps to understand deposit evacuation dynamics. The study focuses on the Kanaan Cave, located in Metn District, Lebanon, and reveals new stages related to the cave speleogenesis. This technique could be applied on 'paragenetic' caves where clay volume is frequently present in order to constrain the clay volume and reconstruct the buried floor shape of the cave, underneath the clay deposit.
\end{abstract}

Keywords: $\quad$ speleogenesis; HVSR; sediment thickness; Kanaan Cave; Lebanon

Received 19 July 2012; Revised 2 November 2013; Accepted 25 January 2013

Citation: Nehmé C., Voisin C., Mariscal A., Gérard P.C., Cornou C., Jabbour-Gédéon B., Amhaz S., Salloum N., Badaro-Saliba N., Adjizian-Gerard J. and Delannoy J.J. 2013. The use of passive seismological imaging in speleogenetic studies: an example from Kanaan Cave, Lebanon. International Journal of Speleology, 42 (2) 97-108. Tampa, FL (USA) ISSN 0392-6672 http://dx.doi.org/10.5038/1827-806X.42.2.1

\section{INTRODUCTION}

Caves are among the most conservative environments in the evolving landscape (De Waele et al., 2009, 2011) and also act as traps of sediments (Farrant \& Smart, 2011). Many speleogenesis studies focused on the role of sediments in cave evolution (Ford \& Ewers, 1978; Quinif, 1988; Lauritzen \& Lauritsen, 1995; Palmer, 2007; Plan, 2010). Sediment deposition in caves can lead, in specific geological contexts, to paragenetic processes (Renault, 1967; Pasini, 2009). Extensively described in the 1960s and 1970s (Renault, 1968), the process of paragenesis occurs in phreatic conditions when clay sediments fill in the cave and accumulate in the lower parts of the cave conduits. Sedimentation often protects these parts of the cave from dissolution that is directed upwards and creates series of typical morphologies such as: dissolution pockets, ceiling half-tubes, pendants, etc (Ford \& Williams, 2007). Paragenetic processes are associated with base-level rise (Mocochain et al., 2006; 2009). Some karst studies revealed that paragenesis can occur in certain regions (e.g. Ardèche Basin, France), where the conditions of evolution of paragenetic caves were favorable, during the Pliocene period (Camus, 2003; Delannoy et al., 2004, 2009; Audra et al., 2009; Blanc, 2010). Paragenetic caves are commonly infilled with clay sediments that can reach several metres height (Perroux, 2005; Jaillet et al., 2007). A similar problem takes place also in the Kanaan Cave located in the village of Nabay, in North-Metn district, $6 \mathrm{~km}$ north east of Beirut city (Fig. 1). It was discovered in 1996, throughout continuous quarrying exploitation in Antelias valley. The massive clay layer of several metres height covers the bottom of the cave.

Therefore, speleogenetic studies on paragenetic caves are limited to the observation of morphologies seen on ceiling and cave walls when the sediments are not totally evacuated from the cave. These studies based only on observation of geomorphology cannot reveal the 


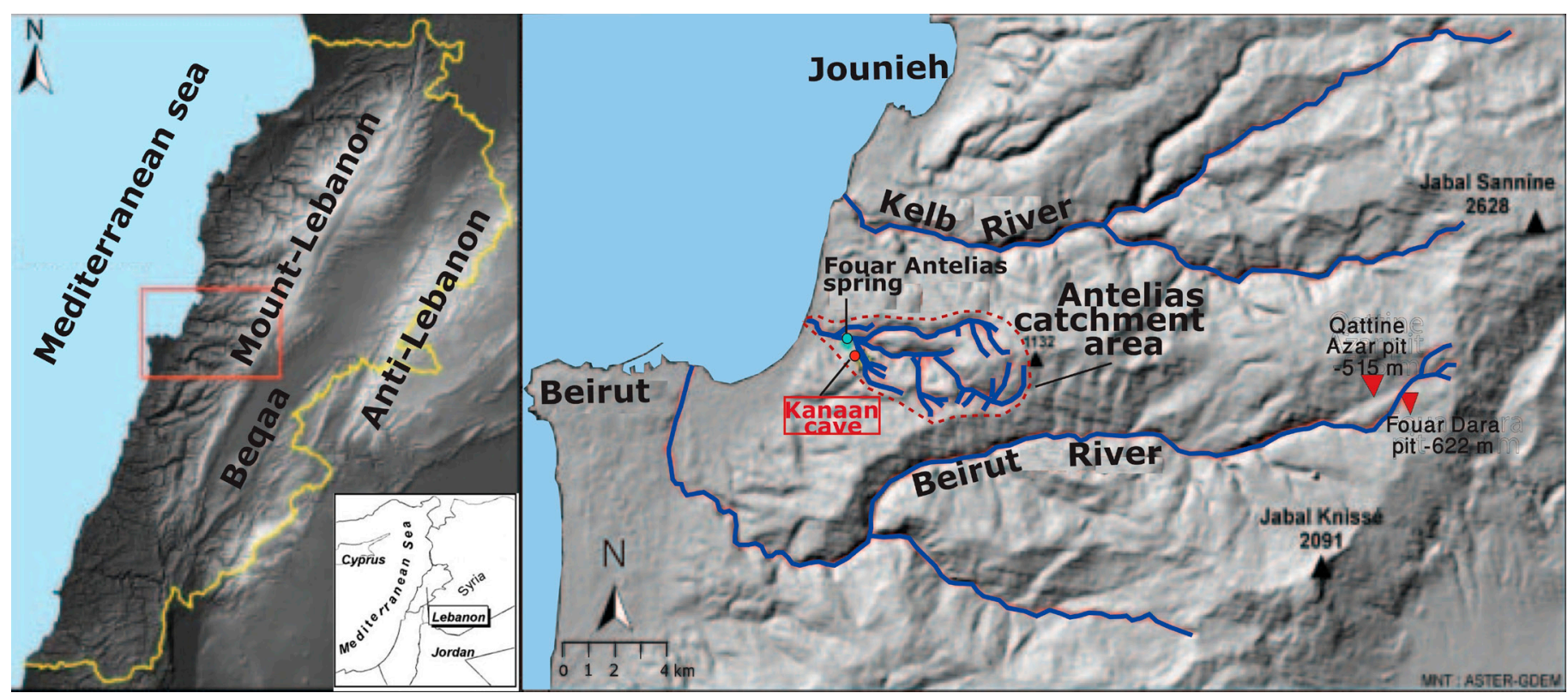

Fig. 1. Left: General map of Lebanon. The country is divided in the Mount Lebanon chain, the Anti Lebanon chain, separated by the Bekaa Valley. Right: zoom in from Beirut to jounieh showing the location of the Kanaan Cave with respect to the main features of the local hydrology.

dynamics of the cave such as collapse phases or clay evacuation during cave evolution history. This paper proposes the use of a passive imaging technique that can be applied on clay deposits in caves as one possible method to complete the method of geomorphologic mapping (Delannoy, 2001) for speleogenetic studies.

Many geophysical methods commonly used in exploration have potential application to geoenvironmental investigations in karstic terrains, such as seismic methods (Nakamura, 1989), ground penetrating radar (GPR) technique (Milsom, 1996), and electrical resistivity tomography (ERT) (Warner, 1969, Telford et al., 1990). Seismic methods such as HVSR (Horizontal to Vertical Spectral Ratio) or Nakamura's method (Nakamura, 1989) are commonly used in the field of seismic hazard to evaluate seismic wave's amplification in sediments sites (Lachet et al., 1996). This survey method can also be used for geological mapping, primarily in areas covered by vegetation and Quaternary sediments, and provides information on the depth of soft cover layers (Ibs-Von Seht \& Wohlemberg, 1999). Seismic methods and GPR can also be used to trace caves (Chamberlain et al., 2000) and determine soil thickness in archeological sites (Blais, 1999; Hobléa, 2000). Both methods are applicable to the identification of air- or waterfilled openings (Hoover et al., 1992). However, GPR techniques commonly used in archeological sites can be inefficient when applied on surficial wet clay layers, because of the strong signal attenuation in these types of soils (Jessop, 1995).

Electrical resistivity techniques (ERT) are widely applied in karstic terrains. It can be exploited for geological and hydrogeological research, such as: i) tracing cave systems (Gibson et al., 2004; Guerin et al., 2009), ii) searching for discontinuities in limestone rocks (Harvitch \& Valenta, 2011) and determine soil depth in covered karst terrains (Zhou et al., 2000). It can also provide useful data for natural hazards (collapse) in karst terrains (Brinkman et al., 2008; Cooper et al.,
2011). These techniques can be used also in subsurface investigations and can determine deposit thickness in archeological sites (Burger, 1992), mines and caves (Kauffman, 2002). However, electrical resistivity signals are less accurate when it comes to identify clay thickness near cave walls, due to edge effects (Kauffman, 2002).

This paper proposes to use HVSR passive imaging technique for several reasons: (i) this seismic method is a non-disruptive procedure adapted to a hilly landscape and does not require the use of trial pits or drilling, precluded in archaeological caves; (ii) This technique is widely used in classical seismology and leads to estimate both velocity and depth of soft sediments (sand, clay) lying over rocks (limestone; granite), i.e. presenting a large impedance contrast between both materials. A cave is suitable to test this technique, because of the very soft clays lying over hard limestone rocks; (iii) we generate a 3D seismic map of the depth of clay in the Kanaan Cave derived from a HVSR survey. The results are validated using data from an ERT traverse across the sediment fill. Both methods are consistent and improve observation of the lower and bottom part of the Kanaan Cave conduit and provide additional answers for speleogenesis stages of Kanaan Cave.

\section{Cave description}

The Kanaan Cave is located $98 \mathrm{~m}$ above Mediterranean Sea level and $30 \mathrm{~m}$ above Antelias river thalweg. The cave is a relict conduit and now disconnected from the active hydrological network of Antelias Spring System. The cave is 162 metres long and can be divide in three main areas (Nader, 1998; Nehme et al., 2009b) (see Fig. 2): i) the entrance gallery updated during the exploration of the cave. The entry shows some fragments of drapery and calcite flowstone; ii) the collapse areas formed by two chambers (collapse I and II) (Fig. 3) located on both sides of the entrance gallery. Blocks fallen from the roof top and clay sediment constitute the main deposit of this part; iii) the calcite area (the corridor 


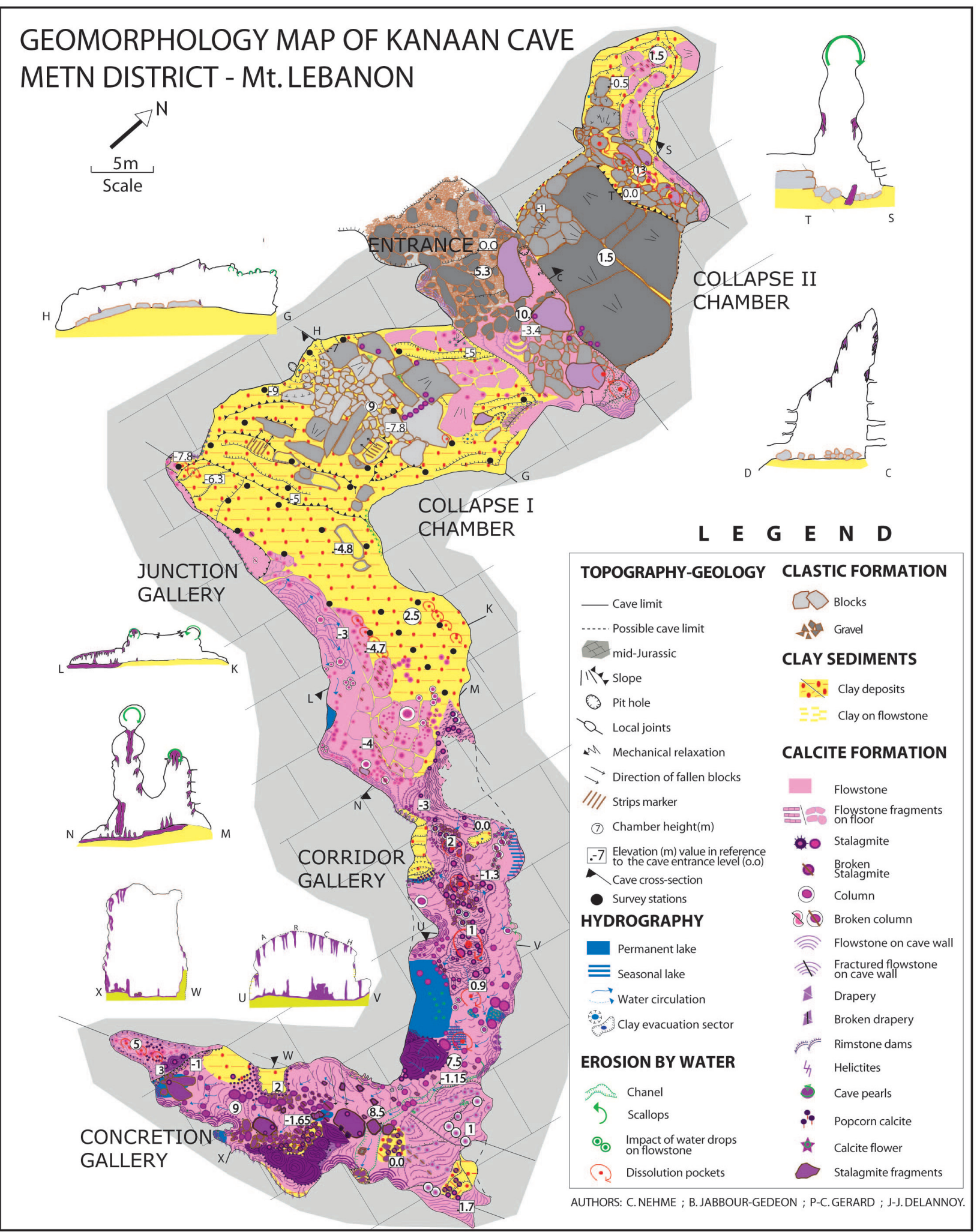

Fig. 2. The geomorphological map of the Kanaan Cave.

calcite gallery) in the deepest part of the cave (Fig. 4) is filled with stalagmites and calcite formations (flowstone, stalactites, stalagmites, cave pearls, calcite curtains ...) that cover a large volume of clay deposits. Several studies were undertaken in Kanaan Cave: i) analysis on petrographic characteristics of cave pearl formations (Nader, 1998; 2007), ii) phases of valley incision and paleogeographical reconstructions based on cave geomorphology (Nehme et al., 2009a) , and iii) paleoseismic data for a better seismic hazard analysis (Lacave et al., 2011).

\section{GEOMORPHOLOGY AND GEOLOGICAL SETTINGS}

The Lebanese landscape is characterized by two mountain chains (Mount-Lebanon and Anti-Lebanon) separated by the Bekaa Plain (Fig. 1) with a variety of surface karstic forms as well as endokarstic network systems. Both mountain chains are formed by middle and upper Jurassic limestone and dolostone formations. Cretaceous rocks cover mountains flanks. The western chain (Mount-Lebanon) is a 


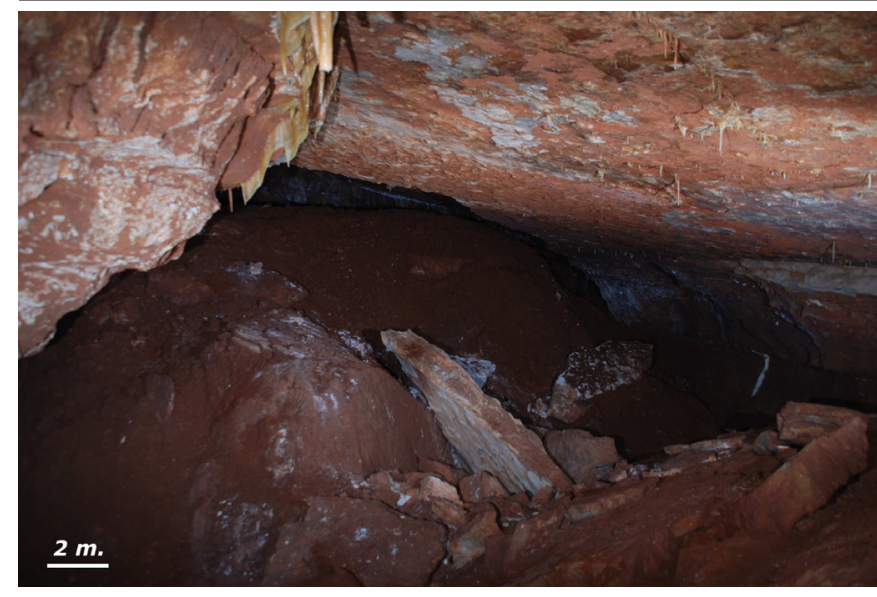

Fig. 3. Photo of the clay outcrop inside the Kanaan Cave, Collapse chamber A buried block is visible $50 \mathrm{~cm}$ below the upper surface of the clay deposit. That depth is consistent with the one revealed by HVSR.

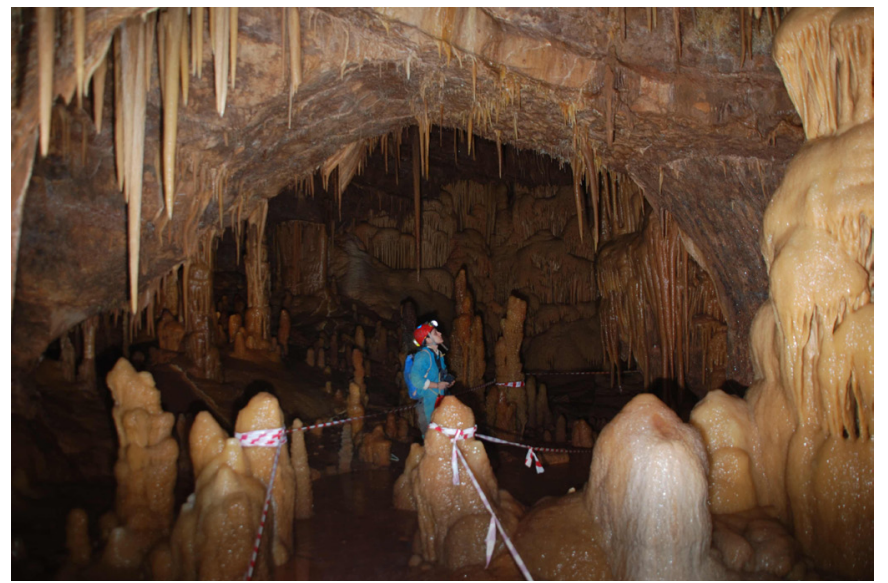

Fig. 4. In the calcite area, the corridor gallery shows different types of calcite formations (drapery; flowstone; speleothems). The flowstone covers the clay sediment. In the ceiling, we observe several arches separated by cupolas of several metres height.

NNE-SSW monocline (Dubertret, 1955) and borders the Mediterranean Sea. The northern part of MountLebanon (ML) rises to a series of plateaus more than $3000 \mathrm{~m}$ height. The mountain displays gentle slopes on its eastern flank and steeper ones on its western side. Along the coastline sector, the Cretaceous formations are made of steeply dipping beds (45 to $90^{\circ}$ of dip angle), generally parallel to ML western flexure trend (Walley, 1998).

The area of study is located in the central part of ML chain. Located $10 \mathrm{~km}$ north of Beirut city, the Antelias River has $20.4 \mathrm{~km}^{2}$ of catchment area and drains directly to the Mediterranean Sea (Fig. 1). Feeding the Antelias River all over the year, the Fouar Antelias spring catchment area is ten times larger $\left(208 \mathrm{~km}^{2}\right)$ than the Antelias River catchment area: dye tracing (Hakim \& Karakabi, 1988; Labaky, 2005) confirmed a hydrogeological connection between Fouar Antelias Spring and Fouar Dara and Qattine Azar underground rivers located at Tarchich village, in the upper basin of Beirut river (Fig. 1).

The Antelias area is mostly formed by middle Jurassic dolomitic limestone (J4-J5) (Dubertret 1955; Walley, 1998). This extremely karstified area is known for its high concentration of caves and subterranean networks (e.g. Kassarat, Nabaa el-Chataouieh, 22 April, Bear, el-Dahr, Kanaan)
(Fig. 5). The limestone stratum is partially covered, in the upper part of the basin, with sandstone formations (C1) in Bhannès and Bikfaya villages while the downstream part is covered by residual red soil. Both sandstone and red soil constitute the main source of cave deposits in the area. The Aptian (C2)-Albian (C3) formations, located downstream of Antelias river basin, constitute an impermeable level and separate the Jurassic and karstified plateaus from Antelias coastal plain filled with Quaternary deposits. The karstic Fouar Antelias spring is located at $33 \mathrm{~m}$ a.s.1. between the Jurassic limestone and the Cretaceous impermeable Aptian/Albian formations. Thus, this structural contact sets the water table level of the Antelias karst drainage at $33 \mathrm{~m}$ altitude and controls partially the karstification of the area.

The tectonic setting (Walley, 1998; Gédéon, 1999) of Antelias region indicates local and regional faults with a NNE-SSW and E-W orientation. The Kanaan Cave chambers and galleries are NW-SE oriented due to the local fault directions. These faults contribute to the rapid water infiltration into the karst system.

\section{KANNAN CAVE SPELEOGENESIS}

The speleogenesis of Kanaan Cave is divided into three stages (Fig. 6). The speleogenetic reconstitution based on observation of morphology and formations (Nehme et al., 2009a) showed that sediment deposition, in the initial phase of the cave development led to paragenetic processes. The speleogenetic analysis inserted within the geological settings of central Mount-Lebanon area revealed that the cave developed in a palaeo-phreatic zone of the karst (Nehme et al., 2009a) with a high watertable level. The reconstitution of the cave history is proposed by using a relative chronology approach:

Stage 1 (Fig. 6; Phase 1): The initial stage in the cave development is related to a phreatic environment where water slowly circulates in karst fractures and the water base-level is higher than the cave initial level formation. The rate of sediment input exceeds sediment transport through the system and clay deposits fill the cave (Farrant \& Smart, 2011). Water circulates between the clay deposits and the roof contributing to the dissolution of the ceiling. At this stage, Kanaan Cave was simply a thin phreatic channel of less than $50 \mathrm{~cm}$ height. The cave enlargement continues upwards with sediment aggradation filling the conduit until the cave rooftop reaches the water table level. Some phreatic lifts, scallops and clay deposits, notches and dissolution pockets observed on the cave ceiling, were formed during this stage. This process is referred by (Renault, 1968) as 'paragenetic conditions' or 'per ascensum cave erosion process'. The clay deposition in Kanaan Cave was associated with a high water base level. The phreatic zone of Antelias karst is, in this stage, at least above $100 \mathrm{~m}$ a.s.1. and was related to the Antelias thalweg level set at $70 \mathrm{~m}$ above the present thalweg level (30 $\mathrm{m}$ a.s.1.) 


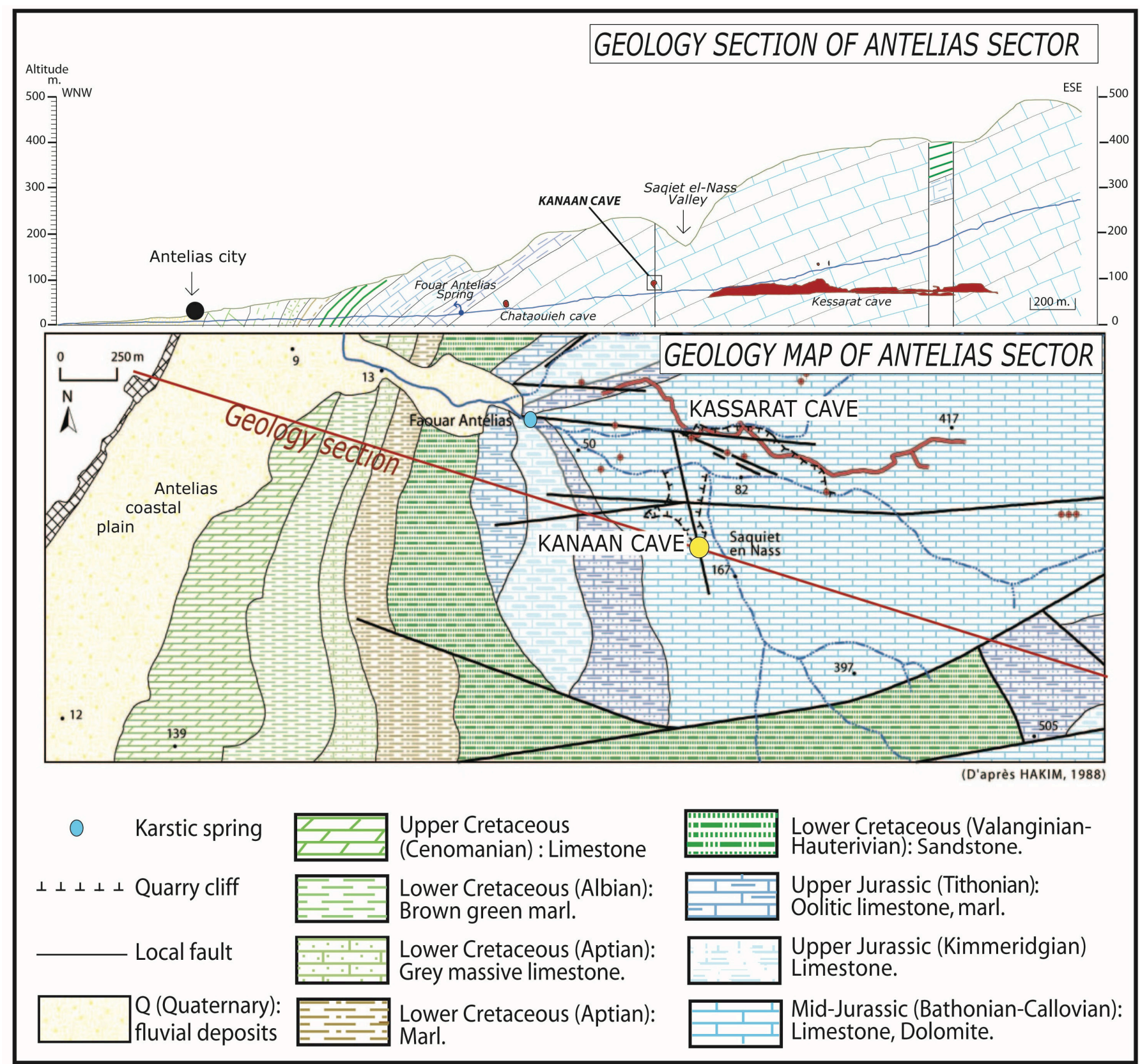

Fig. 5. Geological settings of Antelias sector.

Stage 2 (Fig. 6; phase 2): The Antelias River incised the valley and led to water table level migration downstream of the valley. The cave is disconnected from the Antelias karst system and develops in a vadose environment. It is now located $30 \mathrm{~m}$ above the actual Antelias River thalweg. Kanaan Cave clay deposits are evacuated through cracks and fractures. Clay deposit volume decreases along with the evacuation process.

Stage 3 (Fig. 6; phase III \& IV): Along with the continuous reduction of clay volume, the cave roof begins to collapse due to gravity. Calcite flowstone and stalagmites are formed on clay deposits. However, continuous evacuation of clay deposits crack the flowstone and the stalagmites.

\section{Open questions on the Kanaan Cave}

The current morphology of Kanaan Cave is the result of all three speleogenetic stages described above. However some dissimilarity is observed between the different areas of the cave when it comes to the collapse process. On one hand, collapsed strata from the rooftop are progressively accumulated on the clay deposit of the collapse chambers. On the other hand no evidence of collapse (fallen blocks) has been detected in the calcite area. However, two arches were observed there (Fig. 3) and lead us to suggest a mechanical adjustment of the cave arch in response to the decrease of clay volume (Fig. 2; cave section UV). Similar arches could not be observed in the collapse chambers. These observations led us to address some questions related to the sedimentation process within the cave: what is the depth of the sediment fill? Was the sediment emplaced in a single event, or is it a multistage process? Were there periods of vadose collapse followed by sediment emplacement?

The 3D seismic map and the ERT profile in the area of clay deposits (collapse II and junction chambers) provided new observations and answers regarding the collapse process in Kanaan Cave as well as the deposition of clay sediments. 


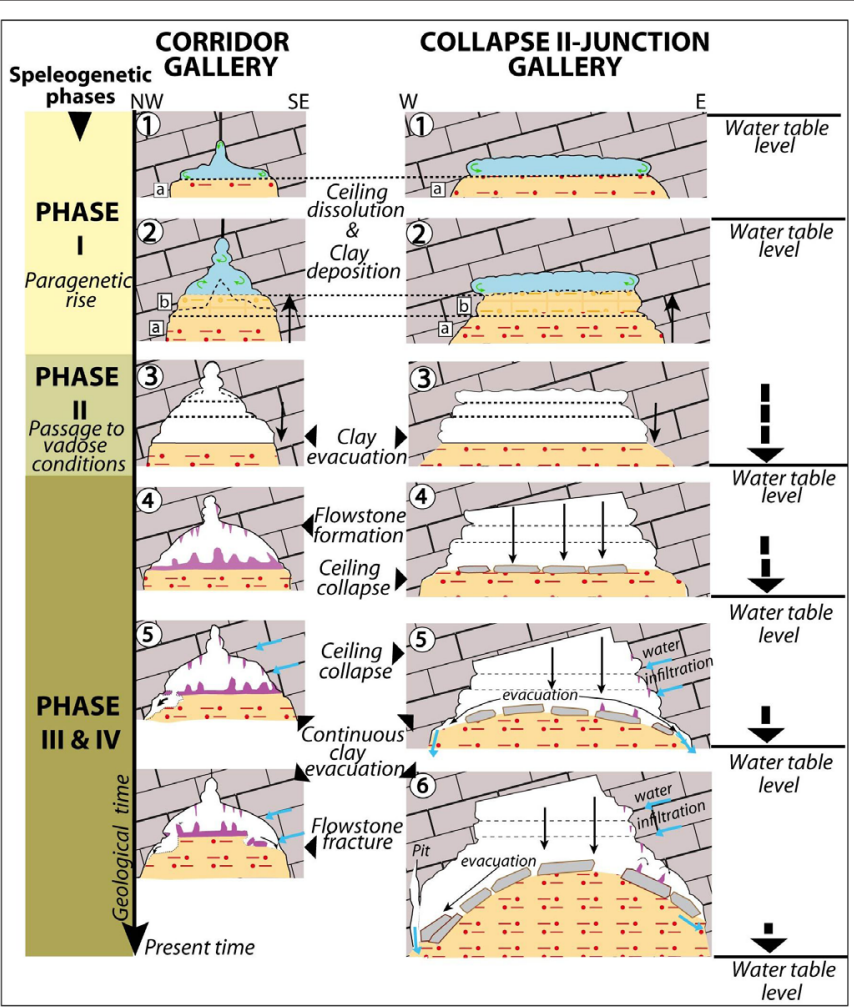

Fig. 6. Schematic speleogenetic reconstruction of the Kanaan Cave.

\section{PASSIVE SEISMIC IMAGING OF THE KANAAN CAVE, LEBANON}

The Kanaan Cave has a large surface of clay deposit with $457 \mathrm{~m}^{2}$ in the Collapse and Junction chambers. The question we tackle here is to estimate the total volume of clay at the present time and to image the depth of clay in several points. In order to preserve the environment of the cave, we make use of a passive technique (HVSR).

\section{The HVSR technique: a quick introduction}

The Earth is continuously shaken by propagating waves (either surface or body waves) whose origin is found in wind and oceanic storms for frequencies lower than $0.3 \mathrm{~Hz}$, as well as in the human activities for frequencies higher than $1 \mathrm{~Hz}$ (Bonnefoy-Claudet et al., 2006a). These waves of small amplitude are referred as to the seismic ambient noise. The passive recording of seismic ambient noise is at the core of the HVSR technique. Seismic recorders are deployed on the volume of clay and record the $3 \mathrm{D}$ seismic ground motion for about 15 minutes. An example of such a recording is given in Figure 7A. The two horizontal components (East and North) are markedly more energetic than the vertical component (Up), as testified by larger amplitudes of motion. This difference in amplitude between horizontal and vertical motions can be seen in the spectral domain that reveals the spectral content of the seismic field, dominated here by the sources of ambient noise, the shape of the cave and the nature of the infillings (Fig. 7B). The amplitude difference exhibits a dependence on the frequency. To further emphasize this difference, the ratio of both spectra is performed (Fig. 7C). In this particular example, we can see that the ratio is close to 1 for low frequencies in the range 0.5 to $5 \mathrm{~Hz}$. The ratio shows a clear and strong peak at a particular frequency called the fundamental frequency $f_{0}$, before going back to 1 .

The HVSR technique is applicable where a soft layer of material stands above a hard substratum. The seismic impedance, defined as the product of the seismic velocity $\beta$ and the volumetric mass $\rho$ plays a primary role in the presence of a peak in the HVSR. Indeed, the seismic energy produced by the different noise sources propagates through the substratum as body or surface waves. For the sake of clarity, imagine a planar wave propagating upward through the substratum. This seismic energy is transmitted to the soft layer, characterized by low impedance and propagates through the soft layer up to the free surface. At this point it is totally reflected and propagates downward until it reaches the interface with the substratum. However, this time the seismic energy is not transmitted again to the substratum, because of the large impedance contrast. The lower interface plays the role of a seismic mirror and the seismic energy is reflected back to the soft layer. In other words, the soft sediment layer acts as a trap for seismic energy.

The wave field in the soft layer is made of upward and downward propagating waves and will behave as a resonator for some frequencies for which incoming waves and previously trapped waves will be in phase, leading to an amplification of the seismic motion at
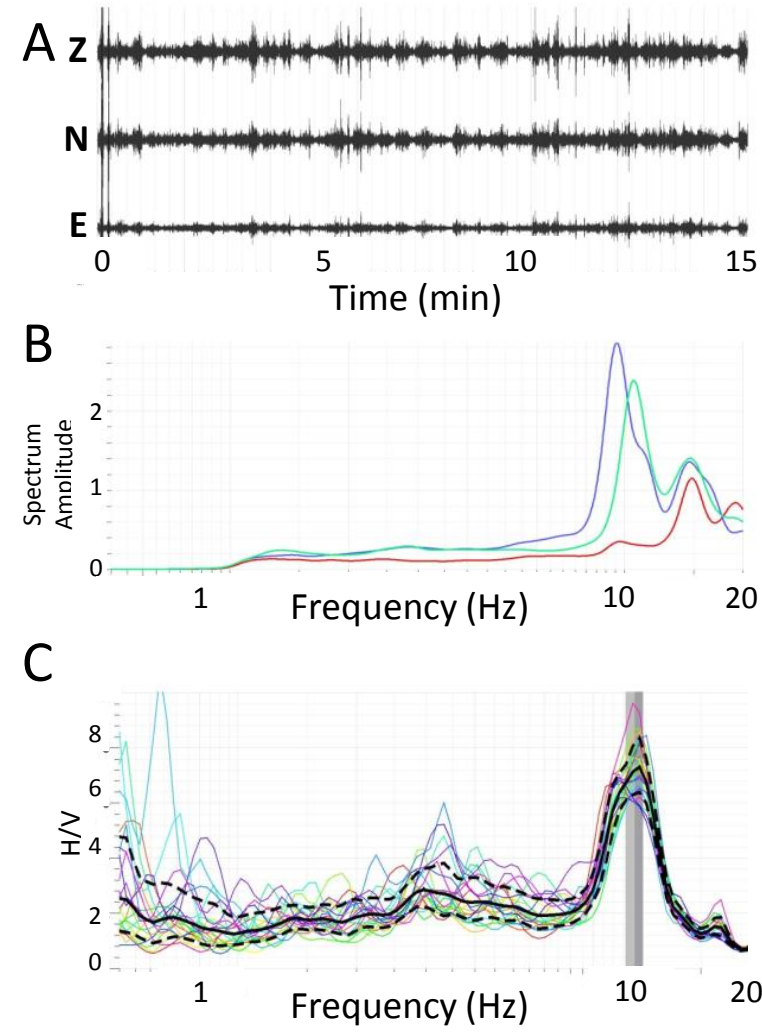

Fig. 7. A: 15 minutes of seismic noise measurements recorded inside the cave at $100 \mathrm{~Hz}$ of sampling. We show here the three components (East, North, Vertical in order). Note the continuous vibration of the ground and the strong variations in amplitude. B: Estimation of the spectrum of each component (blue and green: horizontal components; red: vertical component). Note the strong peaks visible in the horizontal components around $10 \mathrm{~Hz}$. C: Horizontal to Vertical Spectral Ratio (HVSR) reveals the fundamental frequency of resonance $f_{0}, 10 \mathrm{~Hz}$ in this example. 
those frequencies. As a consequence, the HVSR will show a peak at each of these frequencies. The lowest of these frequencies is called the fundamental frequency of resonance $f_{0}$. It is intuitive that $f_{0}$ (and its multiples) will depend on the seismic velocity inside the soft layer, the thickness of the layer, and on the shape of the soft layer. Bonnefoy-Claudet et al. (2006b) showed that those peaks in the HVSR can be linked to the Rayleigh ellipticity peak, the Airy phase of the Love waves and/or the resonance frequencies depending on the proportion of these different types of waves in the ambient noise. These values give, approximately, the same result for a given ground. The HVSR could be a reliable method to estimate the resonance frequency of a particular site. Assuming a 1D problem (that is a soft layer infinite in both horizontal directions), it was shown for a unique sediment layer lying over the bedrock, that this value $f_{0}$ is related to the velocity of S-waves $\beta$ and the thickness of the sediment layer $H$ following:

$$
f_{o}=\beta / 4 H
$$

It can therefore be used to map the bedrock depth, once we know the S-wave velocity in the soft layer.

\section{APPLICATION OF PASSIVE IMAGING METHOD IN KANAAN CAVE}

The Kanaan Cave is characterized by a large clay volume that will be the object of our investigation. It will act as a soft layer resonating over the hard limestone. The survey is performed with Taurus seismic stations equipped with 3 components velocimeters (CMG40 by Güralp), usable in the range of 0.03 to $60 \mathrm{~Hz}$.

\section{Fundamental frequency mapping}

The mapping of the thickness of the body of clay requires performing noise measurements every 2-3 metres in both North and East directions. Given the dimensions of the body of clay, the whole survey takes about 130 measurements of seismic noise. At each point, a fundamental frequency is estimated following the procedure described above. These results are then interpolated over the entire body of clay. The fundamental frequency $f_{0}$ ranges from 6 to $50 \mathrm{~Hz}$. The upper limit is set by the sampling frequency of the stations, $100 \mathrm{~Hz}$ in the present study. Interestingly, the clay body that looks so massive and coherent at its surface presents strong contrasts when it comes to $f_{0}$ (Fig. 8). In the lower part of the cave, 5 different areas present $f_{0}$ values higher than $30 \mathrm{~Hz}$. They are located clearly inside the clay, suggesting the presence of buried limestone blocks. On the contrary, the upper part of the cave presents areas of high $f_{0}$ that are located mostly on the edges of the clay body, suggesting this time either a smaller depth of clay or calcite formations buried inside the clay.

Despite the finite dimensions of the clay body that impair the 1D approximation, we apply Equation 1 to derive the depth of the basement below the clay. The measurements presented in Figure 5 provide us with the fundamental frequency $f_{0}$. It is necessary to estimate the wave velocity $\beta$ inside the body of clay to derive the depth $H$.

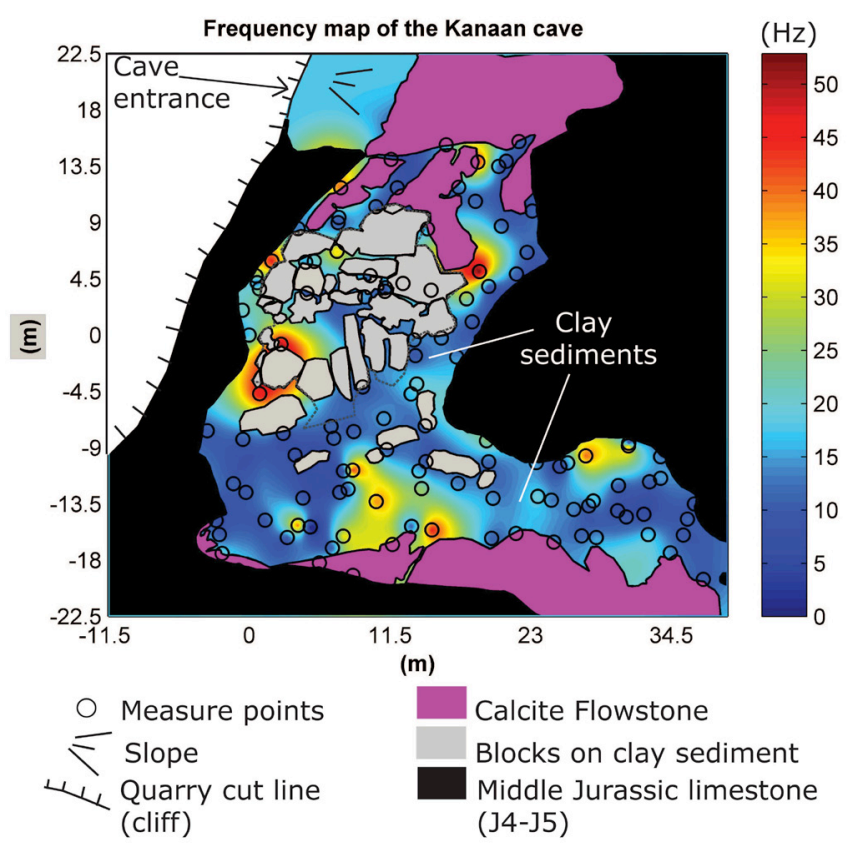

Fig. 8. Map of the fundamental frequency $f_{0}$ over the body of clay. Interestingly, the body of clay that looks so coherent at the surface presents strong lateral variations in terms of frequency of resonance. The range of frequency goes from $6 \mathrm{~Hz}$ up to $50 \mathrm{~Hz}$ (the upper limit due to the sampling of $100 \mathrm{~Hz}$ ).

\section{Estimation of the wave velocity $\boldsymbol{\beta}$}

Different techniques are efficient to measure the speed of seismic waves inside the body of clay. Some of them are active, and require a seismic source strong enough to generate and propagate seismic waves inside a seismic array. The mean wave speed is derived from the time delays between pairs of stations and their distance. However, given the constraint to preserve the environment of the cave as much as possible, we have used passive techniques to estimate the velocity. The wave velocity is derived by cross-correlation of the seismic noise records at the different stations operating at the same time. The average distance between the operating stations is about 2-3 metres. We are confident that the seismic wave field remains highly coherent when propagating between the stations: this is absolutely required to obtain a significant cross-correlation. This technique has the advantage to use the same dataset used to estimate the fundamental frequency, and does not require extra measurements. The cross-correlation is performed on the 15 minutes of continuous recording between all possible pairs of stations. The velocity $\beta$ ranges between 100 and $450 \mathrm{~m} / \mathrm{s}$. The lower limit for $\beta$ is typical for unconsolidated clays. We will consider here that we have pure clay wherever we meet this low velocity. The upper limit is not typical either for clays or for limestone, whose velocity is higher than $2500 \mathrm{~m} / \mathrm{s}$ which is the limit that we could measure with the distances and the sampling frequency used in this study. A value of $450 \mathrm{~m} / \mathrm{s}$ is somewhere in between the two end-members, clay and limestone, and is interpreted here as the average velocity along a path that encompasses both end-members. That is there has to be a limestone block somewhere along the path considered between the stations. 


\section{Estimation of clay thickness}

When $f_{0}$ and $\beta$ are estimated, it is possible to estimate the depth $H$ of clay. However, cautiousness is required before applying Equation 1. This would be straightforward if we had only pure clay inside the body. However the presence of a limestone block hidden somewhere inside has two effects. The first one is to increase the fundamental frequency $f_{0}$ because the presence of the block limits the apparent thickness of the clay. And the second one is to increase the wave velocity $\beta$. Applying Equation 1 in such a case would imply that we take into account the limestone block two times. It is required to use the velocity of pure clay (that is the lower limit measured above: $100 \mathrm{~m} / \mathrm{s}$ ) to make sure that we do not include the limestone effects in the computation. Figure 9 presents the map of $H$, the depth of clay below the surface computed for a wave velocity of $100 \mathrm{~m} / \mathrm{s}$. Assuming a 1D model below each point of measurement, it is possible to map the variations of depth all over the body of clay. As can be seen in Figure 7, $H$ is ranging from 0.5 up to 3.5 metres. These results need to be validated by direct observations. For the same constraint of preservation of the environment of the cave, drillings were absolutely excluded. A direct observation is possible in the slope of the body of clay, in a place where a buried block is visible in outcrop. The apparent depth of this block $(1.5 \mathrm{~m}$ below the surface of the clay) is coherent with the estimated thickness of clay at this position derived from HVSR (between 1.5 $\mathrm{m}$ and 2 metres).

Another validation comes from the Electric Resistivity Tomography (ERT) that we performed along the longest dimension of the body of clay. This technique has shown strong limitations in the context of caves, due to edge effects that can dominate the signal. To minimize these effects, we have performed an ERT profile in the middle of the body of clay and

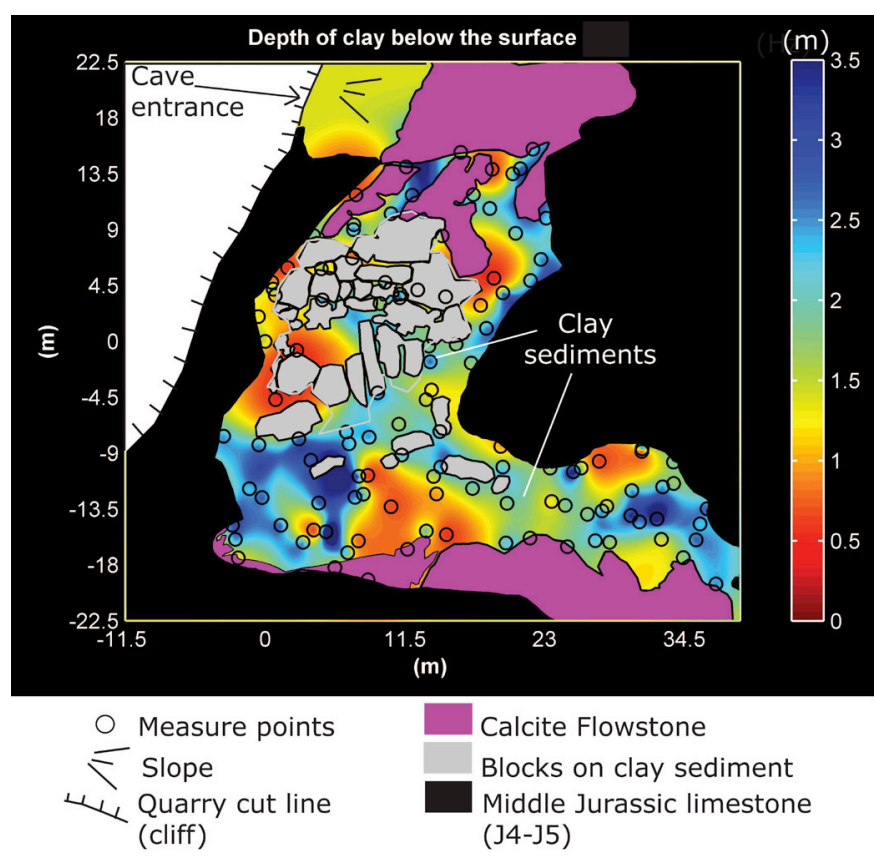

Fig. 9. Map of the depth of clay below the surface. The clay thickness is computed from Equation (1) with an imposed velocity of $100 \mathrm{~m} / \mathrm{s}$. The frequency map in Figure 6 directly converts to this map of thickness. The high frequencies turn into thin clay deposits, and low frequencies turn into thick clay deposits. passing over the buried block visible in the slope (Fig. 10). The electrodes were spaced every $20 \mathrm{~cm}$ over the $25 \mathrm{~m}$ of extension of the clay body. Limited by the number of electrodes, such a short distance does not allow the ERT technique to image the subsurface at depth greater than $4 \mathrm{~m}$. The overall thickness variations measured by HVSR along the east-west axis of the body of clay are coherent with the results revealed by the ERT profile. In addition, the large contrast of resistivity between limestone and clay makes the ERT technique suitable to image the blocks of limestone buried inside the body of clay. The buried block visible in the slope is identified in the ERT profile by a resistivity of 1200 Ohm. Three more buried blocks appear along the ERT profile, located half a metre below the surface, in the central part of the junction gallery. These locations are also coherent with the estimated thickness derived from HVSR at these locations and estimated between 0.5 and 1 metre. Both techniques and the direct observation of buried blocks are coherent and provide reasonable estimates of the thickness of clay at every point as well as the position of buried blocks of limestone that are not visible at the surface of the clay.

\section{RESULTS AND DISCUSSION: REVISITING THE SPELEOGENESIS OF THE KANAAN CAVE}

The collapse II chamber is characterized by low thickness of clay. This could be explained by the deposit dynamics affecting this area and discharging the clay volume further down under the cave level. In detail, we observe several areas characterized by a thin layer of clay ( 0 to $1 \mathrm{~m}$ thick), located west of the chamber. They are probably attributed to clay evacuation points. These evacuation areas are aligned along the west wall and follow the orientation of a NESW fault, partly visible from the cave entrance (Fig. 11). The fallen blocks dipping to the west confirm also the evacuation process in this area. The eastern and northern sectors of the collapse II chamber are characterized by a thick layer of clay (up to 3.5 metres) at the exception of two areas already known from the geomorphological analysis of the cave. These two sectors are less affected by the clay evacuation. The clay thickness and the flat surface floor level in the northern sector of the chamber correspond to the clay deposits level and thickness in the Junction gallery (Fig. 12). Variations of clay deposit thickness in the Junction chamber are related to different processes from those revealed by clay variation analysis in the collapse chamber. First, areas with thin clay deposits are located in the center of Junction chamber. It corresponds to a small accumulation of deposits on buried blocks fallen before the clay deposited. The clay thickness reaches 3 to 3.5 metres to the east and west of the gallery. In the extreme western part of the junction gallery, the thickness of clay varies rapidly from a deep level (3.5 metres) surrounded by two thinner clay areas ( 1 to 1.5 metres). The ceiling in this sector shows no form related to collapse of blocks, but 
ERT PROFIL
(model resistivity with cave topography)

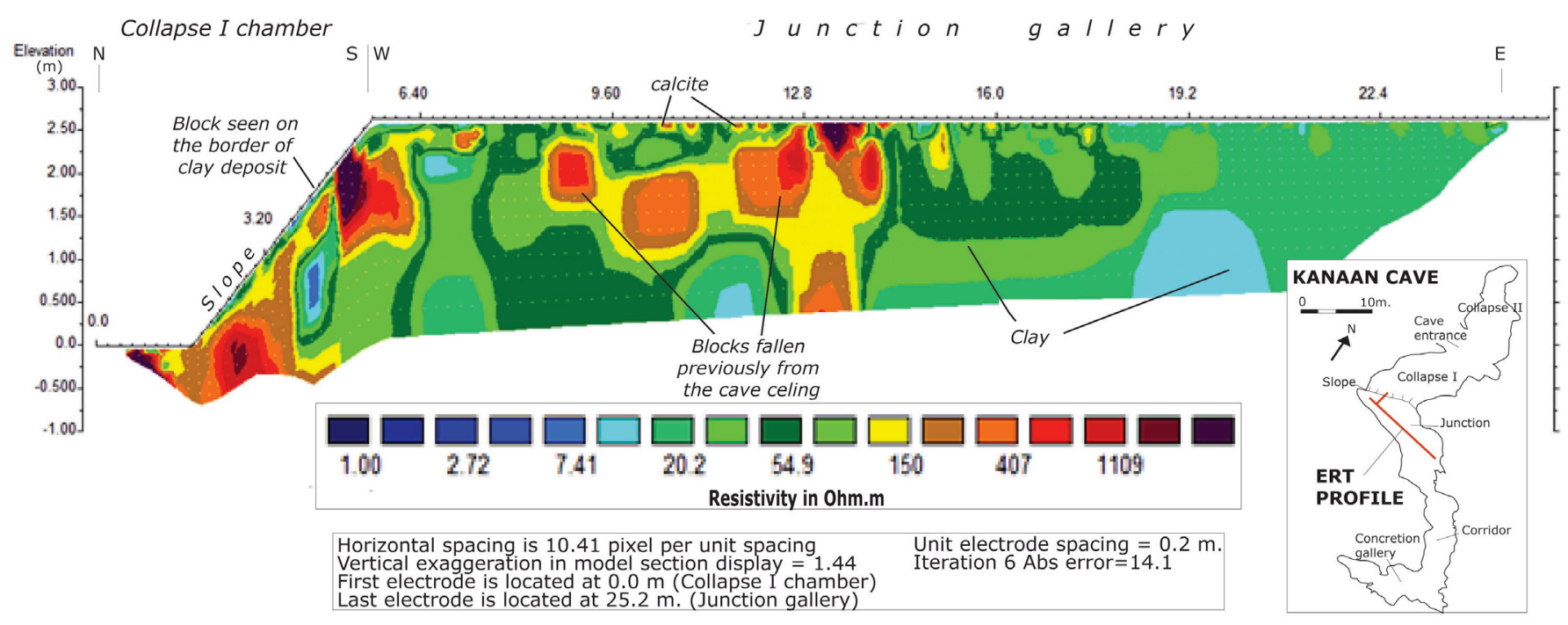

Fig. 10. The ERT profile in the Junction room (EW orientation) is obtained from a combined inversion of two acquisitions in the dipole-dipole configuration. It reveals high resistivity blocks buried in the body of clay. These buried bodies correlate quite well with the thin clay deposit derived from the HVSR technique. The short length of the ERT profile $(25 \mathrm{~m})$ limits the depth of penetration to $4 \mathrm{~m}$. The lateral resolution is excellent immediately below the surface and decreases with depth.

rather dissolution forms such as pockets. Therefore, this depth variation of the clay deposit can be attributed to the original shape of the buried conduit (Fig. 10). The section of the conduit is narrow at its edges and deep in the centre, describing a smooth $\mathrm{V}$ shape conduit. Buried blocks, located $50 \mathrm{~cm}$ from the surface are related maybe to previous collapse episodes.

HVSR and ERT methods allowed us to precise the depth of clay sediments and redefine the Kanaan Cave cross-section with more accurate clay depth variations (Fig. 13).

Speleogenetic analysis showed that Kanaan Cave developed in phreatic conditions with clay accumulation processes in the first initial cave development (Nehme et al., 2009b). Clay accumulation reaches $4 \mathrm{~m}$ in height. However, HVSR map and ERT transect showed several buried blocks under $0.5 \mathrm{~m}$ of sediments. This new observation can be interpreted as the result of two different speleogenetic scenarios.

SECTION OF THE COLLAPSE II CHAMBER (North sector)

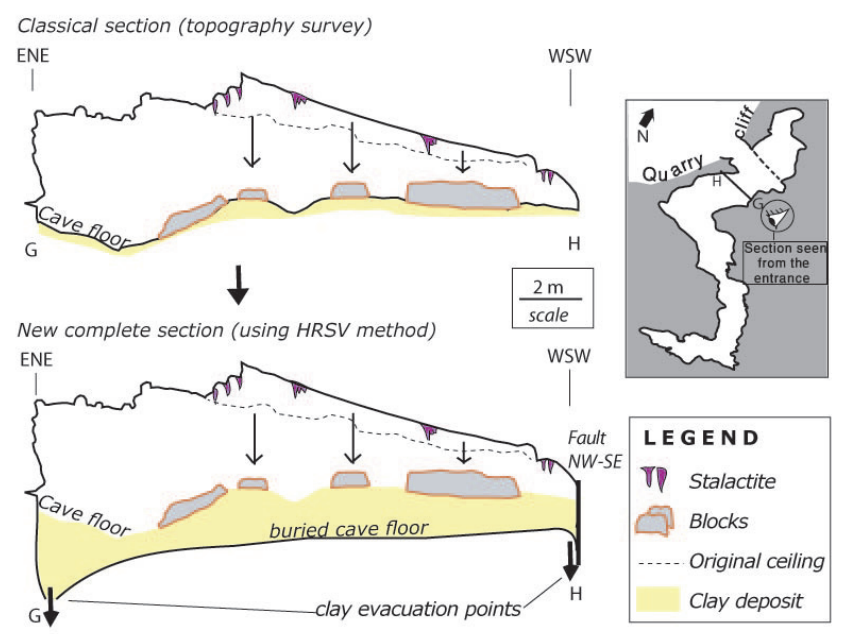

Fig. 11. Reconstruction of the collapse chamber section.

\section{SECTION OF THE JUNCTION GALLERY}
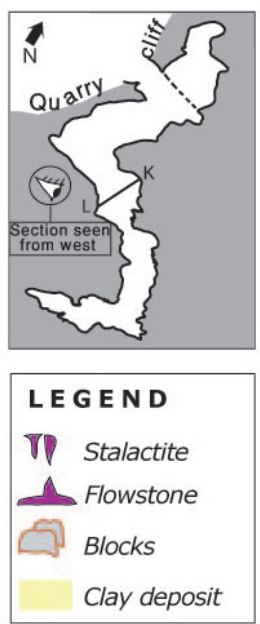

Classical section (topography survey)

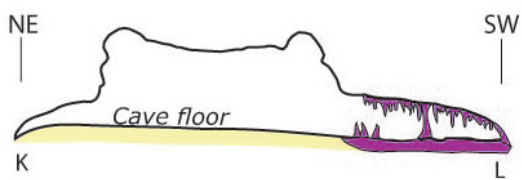

New complete section (using HRSV method)

NE

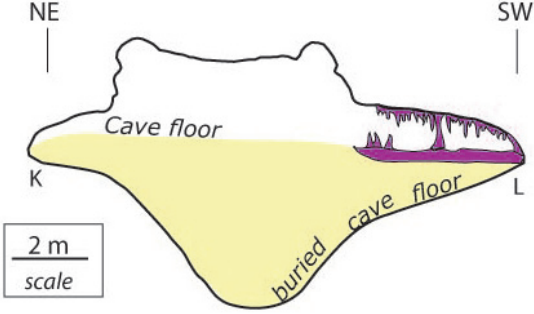

Fig. 12. Reconstruction of the Junction chamber section.

First scenario: Kanaan Cave developed in phreatic conditions when the sediments filled in the cave. Then Kanaan Cave developed in a vadose phase when the watertable level begins to migrate downstream the valley along with the incision of the thalweg. Clay evacuation was then possible and collapse processes took place. However a new phase of deposition occurs on previous fallen blocks. This could probably result from a reactivation of water circulation in the cave due to the fluctuation of the water table near the Kanaan Cave level. The final and present stage of the cave evolution history is related to the lowering of the watertable level set at $33 \mathrm{~m}$ altitude (current level of Antelias spring). Sediments evacuation and vadose collapse processes are initiated. Small pits are observed in the Collapse chamber (Fig. 6; stage III and IV; scheme 6) as well as outside the cave entrance (Nehme et al., 2009b). These observations explain that the current variations in clay thickness are due to evacuation processes. 


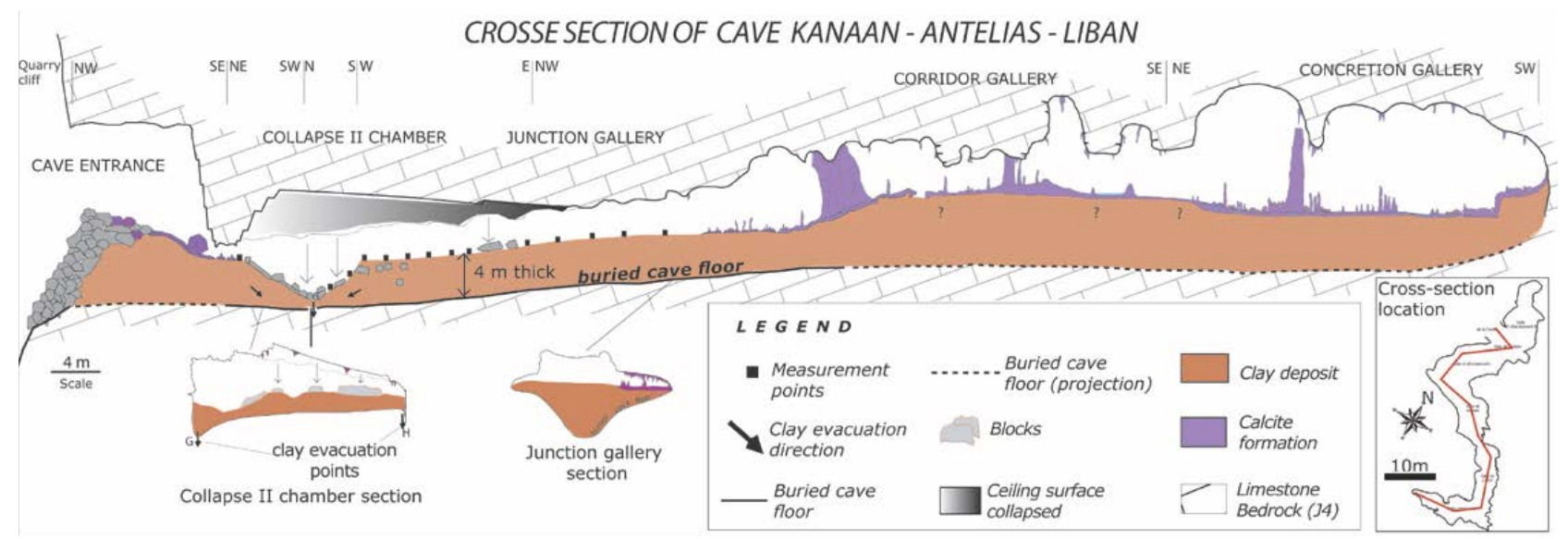

Fig. 13. Kanaan Cave profile, with an integration of clay depth values.

In this case, sediment emplacement in the cave is a multistage process with two vadose collapse phases separated by deposition processes.

Second scenario: the deposition process results from a single event. Sediment emplacement occurs in the first initial cave development in the phreatic zone of the karst. The watertable level and the elevation of Antelias thalweg were higher than Kanaan Cave level $(-100 \mathrm{~m})$. The watertable lowering downstream the valley along with the incision of the thalweg led to the evacuation of sediments and vadose collapse. Fallen blocks underneath clay sediments could be, in this case, the result of liquefaction processes of wet clay deposits. This process caused fallen blocks on resting on the clay surface to penetrate slowly into the clay deposit.

Both scenarios for cave speleogenesis are to be confirmed by conducting further analysis on sediments and by extending geomorphological observations on other similar caves in the Antelias region.

\section{CONCLUSIONS}

The Kanaan Cave has revealed a complex speleogenetic history with stages of sediment emplacement and evacuation related to the evolution of the karst watertable level. New means of survey such as the passive technique in caves, offers further information that help to reconstruct different phases of cave speleogenesis. Using a passive imagery technique, we could define the bottom of the clay body and reveal the shape of the original conduit of the cave, currently covered with up to 4 metres of clay. Different withdrawal areas could be identified from the variation of clay thicknesses. The HVSR is an efficient technique to map clay thickness variations in a cave environment and to identify the buried fallen blocks not accessible to a geomorphological analysis at the surface. The HVSR method is a non-disruptive technique and therefore can be used on hilly topography in archaeological sites and inside caves.

\section{ACKNOWLEDGEMENTS}

We acknowledge financial support from the LIBRIS project (ANR-09-RISK-006). We would like to thank the technical support of ALES (Association Libanaise d'Etudes Spéléologiques) and all the members who accompanied us during field trips. We also thank the anonymous reviewers for their constructive comments and reviews.

\section{REFERENCES}

Audra P., Mocochain L. \& Bigot J.Y., 2009 - Base-Level rise and Per Ascensum model of speleogenesis (PAMS), interpretation of deep phreatic karst, vauclusion springs and chimney shafts. In: White W.B. (ed.), $15^{\text {th }}$ International Congress of Speleology Proceedings, Kerrville, Texas, USA, Vol. 2, 788-794.

Blais J.P., 1999 - Grotte aux Ours (MTS), synthèse des observations géologiques et des mesures géophysiques. Note d'étude (rapport interne), département TEGG division géologie géotechnique, EDF, 22 p.

Blanc J.J., 2010 - Histoire des creusements karstiques et des surfaces d'érosion en Provence occidentale. PhysioGéo géographie physique et environnement, 4: 1-26.

Bonnefoy-Claudet S., Cotton F. \& Bard P.-Y., 2006a The nature of noise wavefield and its applications for site effects studies. A literature review. Earth Science Reviews, 79: 205-227. http://dx.doi.org/10.1016/j.earscirev.2006.07.004

Bonnefoy-Claudet S., Cornou C., Bard P.-Y., Cotton F., Moczo P., Kristek J. \& Fäh D., 2006b - H/V ratio: a tool for site effects evaluation. Results from 1D noise simulations. Geophysical Journal International, 167: 827-837. http://dx.doi.org/10.1111/j.1365-246X.2006.03154.x

Brinkmann, R., Parise, M., Dye, D., 2008 - Sinkhole distribution in a rapidly developing urban environment: Hillsborough County, Tampa Bay area, Florida. Engineering Geology, 99: 169-184. http://dx.doi.org/10.1016/j.enggeo.2007.11.020

Burger H.R., 1992 - Exploration Geophysics of the Shallow Subsurface. Prentice Hall P T R, New Jersey.

Camus H., 2003 - Vallées et réseaux karstiques de la bordure carbonatée sud-cévenole. Relations avec la surrection, le volcanisme et les paléoclimats. $\mathrm{PhD}$ Thesis, Université de Bordeaux, 675 p.

Chamberlain A., Sellers W., Proctor C. \& Coard R., 2000 - Cave detection in limestone using Ground Penetrating Radar. Journal of Archaeological Science, 27: 957-964. http://dx.doi.org/10.1006/jasc.1999.0525

Cooper, A.H., Farrant A.R. \& Price S.J., 2011 - The use of karst geomorphology for planning, hazard avoidance and development in Great Britain. Geomorphology, 134: 118-131. http://dx.doi.org/10.1016/j.geomorph.2011.06.004

Delannoy J.J., Debard E., Ferrier C., Kervaso B. \& Perrette Y., 2001 - La cartographie morphologique souterraine : apports aux reconstitutions paléogéographiques et paléoenvironnementales. Application à la grotte Chauvet, Ardèche, France, Quaternaire, 12 (4): 235-248. http://dx.doi.org/10.3406/quate.2001.1696 
Delannoy J.-J., Perrette Y., Debard E., Ferrier C., Kervazo B., Perroux A.-S., Jaillet S. \& Quinif Y., 2004 - Intérêt de l'approche morphogénique pour la compréhension globale d'une grotte à haute valeur patrimoniale: la grotte Chauvet (Ardeche, France). Karstologia, 44: 25-42.

Delannoy J-J., Gauchon Ch., Hoblea F., Jaillet S., Maire R., Perrette Y., Perroux A.-S., Ployon E. \& Vanara N., 2009 - Le karst: des archives paléogéographiques aux indicateurs de l'environnement. Géomorphologie relief, processus et environnement, 2: 83-94.

De Waele J., Plan L. \& Audra P., 2009 - Recent developments in surface and subsurface karst geomorphology: an introduction. Geomorphology, 106: 1-8.

http://dx.doi.org/10.1016/j.geomorph.2008.09.023

De Waele J., Gutiérrez F., Parise M. \& Plan L., 2011 Geomorphology and natural hazards in karst areas: A review. Geomorphology, 134: 1-8. http://dx.doi.org/10.1016/j.geomorph.2011.08.001

Dubertret L., 1955 - Carte géologique du Liban: Feuille de Beyrouth 1/50000, Ministère des travaux publics, Beyrouth, $74 \mathrm{p}$.

Farrant A. R. \& Smart P.L., 2011 - Role of sediment in speleogenesis; sedimentation and paragenesis. Geomorphology, 134: 79-93.

http://dx.doi.org/10.1016/j.geomorph.2011.06.006

Ford D.C. \& Ewers R.O., 1978 - The development of limestone cave systems in the dimensions of length and depth. Canadian Journal of Earth Science, 15: 1783-1798. http://dx.doi.org/10.1139/e78-186

Ford D.C. \& Williams P., 2007 - Karst hydrogeology and geomorphology. Wiley, Chichester, UK, 562 p.

Gedeon M., 1999 - Structural analysis of latitudinal fault in the Mount-Lebanon north of Beirut : their kinematics and their role in the tectonic evolution of Lebanon. MSc thesis, American University of Beirut, 245 p.

Gibson P.J., Lyle P. \& George P., 2004 - Application of resistivity and magnetometry geophysical techniques for near-surface investigations in karstic terranes in Ireland. Journal of Cave and Karst Studies, 66 (2): 35-38.

Guerin R., Baltassat J.-M., Boucher M., Chalikakis K., Galibert P.-Y., Girard J.-F., Plagnes V. \& Valois R., 2009 - Geophysical characterisation of karstic networks

Application to the Ouysse system (Poumeyssen, France). Comptes Rendus Geosciences, 341: 810-817. http://dx.doi.org/10.1016/j.crte.2009.08.005

Harvitch F. \& Valenta J., 2011 - The identification of faults using morphostructural and geophysical methods: a case study from Strasin cave site. Acta geodynamica et geomaterialia, 8 (4): 425-441.

Hobléa F., 2000 - L'appareil qui a vu l'homme qui a vu l'ours. Spéléo magazine, 34: 28-29.

Hoover D.B., Heran W.D. \& Hill P.L. (Eds.), 1992 - The geophysical expression of selected mineral deposit models. U.S. Geological Survey Open-file Report 92-557, 129 p.

Hakim B. \& Karkabi S., 1988 - Coloration du gouffre de Faouar Dara et de la grotte des Kessarat. Al-OuatOuat, 3: 18-31.

Ibs-von Seht M. \& Wohlenberg J., 1999 - Microtremor Measurements Used to Map Thickness of Soft Sediments. Bulletin of the Seismological Society of America, 89: 250-259.

Jaillet S., Delannoy J.-J., Bersihand J.-L., Noury M., Sadier B. \& Tocino S., 2007 - L'aven d'Orgnac: un grand réseau paragénétique, étude spéléologique des grands volumes karstifiés. In : Delannoy J.-J., Gauchon C. \& Jaillet S. (Eds.), L'Aven d'Orgnac - Valorisation touristique, apports scientifiques. Collection Edytem, Cahiers de Géographie, 5: 57-78.
Jessop J.A., Hauser K.L. \& Gese D.D., 1995 - Evaluation of geophysical methods for locating subsurface hazards in the Shawnee National Forest. Conference on the Environment and Safety, Colorado Springs CO, April 24-28, 1995; Abstract Book, 26.

Kauffman O., 2002 - Rapport de synthèse de la prospection géophysique réalisée dans la salle Plane de l'Aven d'Orgnac. Rapport interne, Université de Savoie, EDYTEM, 12 p.

Labaky W., 2005 - A semi-quantitative description of a dye tracing Experiment in the fouar Antelias drainage Basin. Al-Ouat-Ouat, 13: 28-35.

Lacave et al., 2011 - Contribution à la Caractérisation de l'Aléa Sismique du Liban par l'Etude des Spéléothèmes. $8^{\text {ème }}$ Colloque National AFPS 2011, Ecole des Ponts ParisTech, 1-8.

Lachet C., Hatzfeld D., Bard P.-Y., Theodulidis N., Papaloannou C. \& Savvaidis A., 1996 - Site effects and microzonation in the city of Thessaloniki (Greece). Comparison of different approaches. Bulletin of the Seismological Society of America, 86: 1692-1703.

Lauritzen S.-E. \& Lauritsen A., 1995 - Differential diagnosis of paragenetic and vadose canyons. Cave and Karst Science, 21: 55-59.

Milsom J., 1996 - Field Geophysics. 3rd edition. Chichester, Wiley, 187 p.

Mocochain L., Clauzon G., Bigot J.-Y. \& Brunet P., 2006 - Geodynamic evolution of the perimediterranean karst during the Messinian and the Pliocene: evidence from the Ardèche and the Rhone Valley systems canyons, Southern France. Sedimentary Geology, 188-189: 219-233. http://dx.doi.org/10.1016/j.sedgeo.2006.03.006

Mocochain L., Audra P., Clauzon G., Bellier O., Bigot J.Y., Parize O. \& Monteil P., 2009 - The effect of river dynamics induced by the Messinian Salinity Crisis on karst landscape and caves: example of the Lower Ardèche river (mid Rhone valley). Geomorphology, 106: 46-61. http://dx.doi.org/10.1016/j.geomorph.2008.09.021

Nader F., 1998 - The Temple of Speleology, Mgharet Kanaan. Al-Ouat-Ouat, 13: 54-63.

Nader F., 2007 - Petrographic and geochemical studies on cave pearls from Kanaan Cave (Lebanon). International Journal of Speleology, 36: 39-50. http://dx.doi.org/10.5038/1827-806X.36.1.4

Nakamura Y., 1989 - A method for dynamic characteristics estimation of subsurface using microtremors on the ground surface. Quarterly Reports of the Railway Technical Research Institute Tokyo, 30 : 25-33.

Nehme C., Jabbour-Gédéon B., Gérard P.-C., Sadier B. \& Delannoy J.-J., 2009a - Reconstitution spéléogénique de la grotte de Kanaan (Antélias, Liban) : contribution à la morphogenèse du nahr Antelias. Karstologia, 54: 21-36.

Nehme C., Jabbour-Gédéon B. \& Gérard P.-C., 2009b - La topographie a grande échelle des cavités souterraines: Intérêt Scientifiques, Speleorient, 5: 71-77.

Palmer A.N., 2007 - Cave Geology. Cave Books, Dayton, Ohio, $454 \mathrm{p}$.

Pasini G., 2009 - A terminological matter: paragenesis, antigravitative erosion or antigravitational erosion. International Journal of Speleology, 38: 129-138. http://dx.doi.org/10.5038/1827-806X.38.2.4

Perroux A.-S., 2005 - Les remplissages détritiques endokarstiques. Contribution méthodologique à la lecture des mémoires paléogéographiques et environnementales. Application aux systèmes karstiques de Choranche (Vercors) et d'Orgnac (BasVivarais). PhD Thesis, Université de Savoie, 418 p. 
Plan L., 2010 - Significance of paragenesis in caves of the Eastern Alps. Geophysical Research Abstracts 12 (EGU2010-14673).

Quinif Y. \& Ek C., 1988 - Les sédiments détritiques des grottes. Aperçu synthétique. Annales de la Société géologique de Belgique, 111: 1-7.

Renault P., 1967 - Contribution à l'étude des actions mécaniques et sédimentologiques dans la spéléogénèse, Annales de Spéléologie, 22 (2): 5-17.

Renault P., 1968 - Contribution à l'étude des actions mécaniques et sédimentologiques dans la spéleogenèse. Annales de Spéléologie, 23: 529-596.

Telford W. M., Geldartt L. P. \& Sheriff R.E., 1990 - Applied Geophysics, 2nd ed., Cambridge University Press, UK. http://dx.doi.org/10.1017/CBO9781139167932
Walley C. D., 1998 - Some outstanding issues in the geology of Lebanon and their importance in the tectonic evolution of the Levantine region. Tectonophysics, 298: 37-62. http://dx.doi.org/10.1016/S0040-1951(98)00177-2 Warner D.L., 1969 - Preliminary field studies using earth resistivity measurements for delineating zones of contaminated ground water. Ground Water, 7 (1): 9-16. http://dx.doi.org/10.1111/j.1745-6584.1969.tb01262.x

Zhou W., Beck B.F. \& Stephenson J.B., 2000 - Reliability of dipole-dipole electrical resistivity tomography for defining depth to bedrock in covered karst terrains. Environmental Geology, 39 (7): 760-766. http://dx.doi.org/10.1007/s002540050491 